\title{
Change in People's Eating Behaviour during Covid-19
}

\section{Covid-19 Süresince Insanların Yeme Davranışındaki Değişim}

\author{
Mehmet ŞİMŞEK ${ }^{\mathrm{a}}$, Mehmet Akif ŞEN ${ }^{\mathrm{b}}$
}

a Dr. Öğr. Üyesi, Giresun Üniversitesi, Turizm Fakültesi, Gastronomi ve Mutfak Sanatları Bölümü, Giresun / TÜRKIYE ORCID ID: 0000-0002-7558-5010

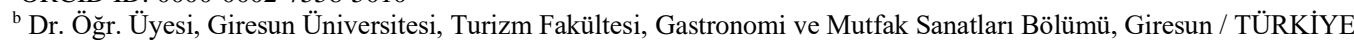
ORCID ID: 0000-0002-2987-8074

\section{A K A L E B İL G İ S İ}

Makale Geçmişi:

Başvuru tarihi: 19 Haziran 2020

Kabul tarihi: 6 Ağustos 2020

\section{Anahtar Kelimeler:}

COVID-19,

Yeme Davranışı,

Duygusal Yeme,

Kontrolsüz Yeme,

Bilişsel Kısıtlama

\section{A R T ICLE INFO}

Article History:

Received June 19, 2020

Accepted August 6, 2020

\section{Keywords:}

COVID-19,

Eating Behaviour,

Emotional Eating,

Uncontrolled Eating,

Cognitive Restraint

\section{ÖZ}

Bu çalışma COVID-19 sürecinde insanların yeme davranışındaki değişimi incelemeye yönelik yapılmıştır. Çalışmanın verileri içinde bulunulan olağanüstü şartlar sebebiyle kısıtlı zamanda ve çevrimiçi anket yoluyla elde edilmiștir. Cevrimiçi anket yoluyla toplanan 397 veri ile gerçekleștirilen T testi analiz sonuçlarına göre COVID-19 sürecinde insanların yeme davranışında bir değişimin olduğu tespit edilmiştir. Bu süreçte yeme davranışına yönelik Bilişsel Kontrol davranışları azalırken, Duygusal Yeme ve Kontrolsüz Yeme davranışı artmıştır. Öte yandan söz konusu davranış değişikliğinin katılımcıların demografik özelliklerine göre farklılaşıp farklılaşmadığı T testi ve Tek yönlü varyans analizi (ANOVA) ile incelenmiştir. Yapılan analiz sonuçlarına göre COVID-19 sürecinde katılımcıların yeme davranıșı yașa ve gelir durumuna göre farklılaşırken, cinsiyete ve eğitim durumuna göre bir farklılaşma göstermemektedir.

* Sorumlu yazar/Corresponding author.

e-posta:mehmet.simsek@giresun.edu.tr 


\section{GENIŞ̧LTILMIŞ ÖZET}

Beslenme ya da yeme davranışının insanlarım yaşamlarını sürdürebilmesi için gerekli olan en temel ihtiyaçlardan biri olduğu ve insanların bu ihtiyacını karşılama aşamasında farklı yeme davranışı gösterdikleri savunulmaktadır. İnsanların yeme davranışını etkileyen genetik, çevresel, psikolojik ve sosyo-ekonomik birçok faktörün olduğu varsayılmaktadır. Psikolojik faktörlerin başında ise stres, depresyon, öfke ve can sıkıntısının geldiği ileri sürülmektedir. Söz konusu bu faktörlerden etkilenen yeme davranışı bozukluğunun obezite ve/veya anoreksiya sebep olduğu, bu durumun ise birçok hastalığın oluşumuna zemin hazırladığ1 iddia edilmektedir. Stresin yeme davranışı üzerindeki etkilerine yönelik yapılan araştırmalar stresin yiyecek tercihi ve satın alma davranışlarındaki değişikliklere sebep olduğu ileri sürmektedir. Söz konusu çalışmalarda stres kaynaklarının daha fazla enerji ve yağ alımı ile ilişkili olduğu ve bu nedenle stres sırasında sağlık açısından birçok zararları bilinen tatlı ve çikolataların bu dönemde daha fazla tüketildiği savunulmaktadır. Öte yandan depresyon ile yeme davranışları arasında pozitif yönlü bir ilişkinin olduğu bilinmektedir. Konuya yönelik yapılan araştırmalar insanlardaki yüksek depresif belirtilerin duygusal yeme davranışlarını olumsuz yönde etkilediğini ve bu durumdaki kişilerin enerji yoğunluğu daha yüksek besinler tüketme eğilimi içerisine girdiklerini ortaya koymaktadır. İnsanların can sıkıntısı anında yemek yeme eğilimi içinde olduğunu ve söz konusu duygu durumlarında daha sık ve daha fazla yeme davranışı içerisinde oldukları belirlenmiştir.

Bilindiği üzere Aralık 2019 tarihinde Çin'de ortaya çıkan ve Dünya Sağlık Örgütü tarafından Pandemi (küresel) olarak ilan edilen COVID-19 bütün dünyada olduğu gibi Türkiye'de de salgına yönelik bir dizi radikal tedbirler alınmasına sebep olmuştur. Belirli yaştakilere yönelik sokağa çıkma yasağı, şehirlerarası seyahat kısıtlaması, sosyal mesafenin yanında birçok işletmenin faaliyetinin geçici olarak durdurulması bu tedbirlerin başında gelmektedir. Alına bu radikal tedbirlerin insanlar üzerinde bazı olumsuz psikolojik etkiler bırakmasının kaçınılmaz olduğu düşünülmektedir. Çünkü söz konusu olağanüstü tedbirler nedeniyle insanlar normal yaşam alışkanlıklarını sürdüremez duruma gelmişlerdir. Bu beklenmedik durumun onların stres, depresyon, can sıkıntısı ve belirsizlik kaygısı duygu durumlarını arttırmış olabileceği varsayılmaktadır. Artan bu olumsuz duygu durumlarının insanların yeme davranışlarında da bazı değişimlere sebep olabileceği düşünülmektedir. Bu düşünceden hareketle bu çalışmada COVID-19 süresince insanların yeme davranışlarındaki değişimin incelenmesi amaçlanmıştır.

Araştırmada örneklem yöntemi olarak tesadüfî örneklem yöntemi ve veri toplama aracı olarak çevrimiçi anket kullanılmıştır. Anket iki aşamadan oluşmakta olup ilk aşamada katılımcıların yeme davranışlarına yönelik 20 soru sorulmuştur. Söz konusu 20 soru Tholin ve ark. (2005) tarafından geliştirilen ve Karakuş ve ark. (2016) tarafından Türkçeye uyarlanan üç faktörlü yeme davranışı ölçeğinden alınmıştır. Katılımcıların bu 20 soruyu yanıtlarken COVID-19 öncesi ve COVID-19 sürecindeki durumlarını dikkate alarak yanıtlamaları istenmiştir. Katılımcılar anketleri 18-31 Mayıs 2020 tarihleri arasında internetten çevrimiçi olarak doldurmuşlardır.

Çalışmaya yönelik anketi toplam 397 kişi doldurmuş olup, anketler bilgisayar ortamına aktarılarak analizler bu veriler üzerinden gerçekleştirilmiştir. Ölçeğin güvenirliğini kontrol etmek için Cronbach Alpha testi yapı geçerliliğine yönelik ise Doğrulayıcı Faktör Analizi yapılmıştır. Yapılan analizler sonucunda ölçeğin güvenirlik ve geçerlilik koşullarını sağladığı sonucuna varılmıştır. Katılımcıların yeme davranışının COVID-19 sürecinde COVID-19 öncesine göre farklılaşıp farklılaşmadığını belirlemek amacıyla yapılan analiz sonuçlarına göre katılımcıların COVID-19 sürecinde bilişsel kısıtlama (BK) davranışlarının azaldığı, Duygusal Yeme (DY) ve Kontrolsüz Yeme (KY) davranışlarının arttığı görülmüştür. Öte yandan katılımcıların COVID19 sürecindeki yeme davranışının demografik özelliklere göre farklılaşıp farklılaşmadığına yönelik analizler yapılmıştır. Yapılan analizlere göre Duygusal Yeme davranışında yaşa göre herhangi bir farklılaşmanın olmadığı ancak Bilişsel Kısıtlama ve Kontrolsüz Yeme davranışında farklılaşma olduğu belirlenmiştir. Yine yapılan analizlere göre katılımcıların Bilişsel Kısıtlama ve Duygusal Yeme davranışında gelir durumuna göre bir farklılık olmadığı, ancak Kontrolsüz Yeme Davranışının gelir durumuna göre farklılaştığı anlaşılmıştır.

COVID-19 sürecinde katılımcıların Bilişsel Kısıtlama davranışında azalma, Duygusal Yeme ve Kontrolsüz Yeme davranışında ise artma olduğu belirlenmiştir. Bu sonuçlar konuya yönelik incelenen çalışmalarla paralellik göstermektedir. COVID-19 sebebiyle İçinde bulunulan olağanüstü ve beklenmedik durumun insanların stres, depresyon ce can sıkıntısı duygu durumlarını tetiklemesi ve/veya arttırması olasılığı yüksektir. Araştırmacılara söz konusu duruma yönelik çalışmalar yaparak sonuçların genellenebilirliğine katkı sağlamaları önerilmektedir.

Yine araştırmacılara COVID-19 sonrasında da yeme davranışına yönelik araştırmalar yaparak COVID-19 sürecinde ortaya çıkan durumun devam edip etmediği, devam etmiyor ise değişimin hangi yönde olduğuna yönelik araştırmalar yapabilecekleri önerilmektedir. Öte yandan yiyecek içecek işletmelerine, tüketicilerinin beklentilerini en doğru şekilde karşılayabilmek için, onlarda oluşan bu yeni yeme davranışına yönelik planlamalar içerisinde olmaları önerilebilir.

Katılımcılardan özellikle gençlerin Bilişsel Kontrol davranışı ortalamaları daha düşük iken, Kontrolsüz Yeme davranışı ortalamalarının daha yüksek olduğu belirlenmiştir. Bu durum gençlerin daha fazla gıda tüketme ihtiyacından kaynaklanabileceği gibi onların stres, can sıkıntısı ve depresyon duygu durumlarını kontrol etmede yetişkinlere oranda daha kırılgan olmalarından kaynaklanabilir. Araştırmacılara COVID-19 sürecinde söz konusu yaş aralığının duygu durumlarına yönelik araştırmalar yapmaları önerilebilir. Öte yandan ilgili bakanlıkların (Sağlık Bakanlığı, Milli Eğitim Bakanlığı gibi.) gençlerin duygu durumları, psikolojilerini ve bu süreçteki yeme davranışlarını düzenleyebilecek programlar geliştirimleri önerilebilir. Bununla birlikte müşteri profili gençlerden oluşan yiyecek içecek işletmelerinin bu durumu göz önünde bulundurarak onların sağlıklı ve dengeli beslenmelerine yardımcı olacak planlamalar içerisinde olmaları önerilmektedir. 


\section{Introduction}

It is argued that eating or eating behaviour is one of the most basic needs required for the maintenance of life, and therefore people have different eating behaviours to satisfy this need (Karakuş, Yıldırım and Büyüköztürk, 2016). It is assumed that there are many genetic, environmental, psychological and socio-economic factors that affect people's eating behaviour. It is suggested that stress, depression, anger and boredom are among the leading psychological factors (Karakuş et al. 2016). It is claimed that eating behaviour disorder, which is affected by these factors, causes obesity and/or anorexia, and this situation paves the way for many diseases (Dovey, 2010). It is believed to be important to examine the eating behaviours and eating behaviour disorders in order to reduce the individual and social effects of the diseases resulting from eating behaviour disorders.

Research on the effects of stress on diet or eating behaviour suggests that stress significantly affects health along with bringing out changes in food choice and purchase behaviour (Zellner et al. 2006). Moreover, it is argued that sources of stress are associated with more energy and fat intake, and therefore desserts and chocolates that are known to have a lot of harm for health are consumed more when people are stressed (Gibson, 2012).

It is known that there is a positive relationship between depression and eating behaviour. Research conducted on the subject has revealed that high depressive symptoms in people affect emotional eating behaviours negatively and people in this situation tend to consume foods with higher energy density (Konttinen, Mannisto, Sarlio-Lahteenlorva, Silventoinen and Haukkala, 2010). Furthermore, many studies have been conducted indicating that people have a tendency to eat when they are bored. In these studies, it has been determined that people eat more frequently and more food when they get bored (Koball, Meers, Storfer-Isser, Domoff and Musher-Eizenman, 2012).

Coronavirus (COVID-19), which first appeared in a seafood and livestock market in Wuhan, China in December 2019, was declared as a pandemic (global) on March 11, 2020 by the World Health Organization (Demir, Günaydın and Demir, 2020). As in the whole world, a series of radical measures have had to be taken against the outbreak in Turkey. Curfews for certain ages, restrictions on intercity travel, social distancing and the temporary suspension of many business activities are among the primary measures (Demir et al. 2020).

It is believed that these radical measures will inevitably have some negative psychological effects on people. Because of these extraordinary measures, people have been unable to maintain their everyday habits. It is assumed that this unexpected situation may have increased their mood of stress, depression, boredom and uncertainty anxiety. It is believed that these increasing negative moods may cause some changes in people's eating behaviour. Based on this idea, the present study aimed to examine the changes in people's eating behaviour during COVID-19. In accordance with the scientific results that will be obtained at the end of the study, suggestions and recommendations can be made to the researchers and food and beverage businesses that are trying to meet their customers' expectations in the best way.

\section{Literature Review}

In the literature review, it is observed that there are quite a few studies on eating behaviours and eating behaviour disorders. Below are several studies on this subject in a chronological order;

A research was carried out by Orbatu (2020) to evaluate Eating Awareness in High School Children in Izmir. According to the data obtained from 2137 students, female students were found to be more sensitive about eating behaviour compared to males. It is argued that 
this may be due to the fact that female students have closer communication with their mothers during childhood, or that male students have more exposure to visual and olfactory stimuli.

Tanriverdi (2020) examined emotional eating behaviours and emotional appetite of university students within the scope of a master's study. The data obtained from 400 students studying at Çankırı Karatekin University indicated that students experienced eating behaviour disorders in situations of tension, when coping with negative emotions and during control against stimuli. In addition, it was determined that eating behaviour disorder significantly differed by gender.

İkiz (2019) examined eating behaviours of the students of Kirıkkale University with the three-factor eating questionnaire (TFEQ). The data obtained from 375 students were used to compare the eating behaviours of the students in terms of gender, body mass index and body weight perception. In the study, it was determined that the correct body perception of the weak and normal weight participants was higher than the participants who were over the normal weight. Moreover, it was concluded that body mass index led to a difference in the cognitive restraint dimension of the eating behaviour, gender did so in the emotional eating dimension, and body weight perception caused a difference in the cognitive restraint and emotional eating dimensions.

The study by Karaoğlu and Erzi (2019) examined the mediating role of self-compassion and emotion dysregulation in the relationship between eating attitudes and childhood traumas in young adults. Research data were obtained from 504 people between the ages of 18-40. According to the analyses performed on these data, it was found that emotional dysregulation and self-compassion played a mediating role in the relationship between eating attitudes and childhood traumas.

İnalkaç and Arslantaş (2018) conducted a compilation study for emotional eating. According to the study, it was determined that individuals consume more food than usual when they get angry or feel under pressure. It is stated that this is emotional eating and can be defined as a type of eating behaviour disorder. In addition, it was emphasized that moods such as stress, depression, parental modelling, anger, boredom and happiness may affect emotional eating.

Altun and Kutlu (2015) conducted a study on the views of adolescents about eating behaviours. As a result of the study, adolescents stated that they mostly consumed foods that were high in carbohydrates and fat and that the foods in protein group were more beneficial for health. Also, they reported that they did not have breakfast habits in the morning and that they were sometimes hungry for a long time during the day, but they also indicated that being healthy meant being accepted by the society.

Higgs (2015) conducted a study to examine social norms and their effects on eating behaviours. According to the results of the study, it was found that social norms were implicit codes of conduct that guided appropriate action, and that social norms related to eating had a strong impact on both food choice and the amounts consumed.

A literature review was carried out by O'Reilly et al. (2014) on obesity-related eating behaviours and mindfulness of the behaviour. According to the results of the 21 articles examined on the subject, they determined that mindfulness-based interventions which targeted eating behaviours had gained popularity in recent years, and these interventions could be listed as mindfulness-based stress reduction, acceptance-based therapies, careful nutrition programs and mindfulness exercises. It was determined that there were negative eating behaviours such as binge eating, emotional eating and external eating among the goals of the interventions.

Groesz et al. (2012) evaluated the relationship between stress and eating motivation in women from normal weight to obese. According to the results of the analysis made with the 
data obtained from 457 women, it was revealed that exposure to or perceiving more stress caused more eating.

Macht (2008) conducted a study on how emotions affect eating. As a result of the study, five dimensions emerged. It was determined that these dimensions were emotional control of food choice, emotional suppression of food intake, cognitive eating controls, eating to regulate emotions and emotion-congruent modulation of eating.

In the studies on the subject detailed above, it is emphasized that eating behaviour may change depending on sociological, psychological and demographic reasons and may affect eating behaviour. In addition, it is revealed that negative emotional states such as tension, anger, stress, boredom and childhood traumas can negatively affect people's eating behaviours. In the light of this information, the study seeks answers to three research questions;

RQ1: What is the eating behaviour of people before COVID-19?

RQ2: How has the eating behaviour of people changed during COVID-19?

RQ3: Does the change in the eating behaviour of people differ according to their demographic characteristics during COVID-19?

\section{Method}

The main purpose of the study is to reveal whether there has been a change in people's eating behaviour during COVID-19. The study also aims to determine whether the possible change in eating behaviour differs according to the demographic characteristics of the participants (age, gender, educational background, etc.). The universe of the study consisted of people who were aged 18 and over and lived in Turkey. In this context, the minimum sample size was determined as 384 (Altunışık et al. 2007).

In the study, simple random sampling method was used to select the participants, and an online questionnaire was employed as data collection tool. The reason for using an online questionnaire is that the extraordinary measures taken due to COVID-19 were still in progress during the research. The questionnaire consisted of two sections; and in the first section, the participants were asked 20 questions aimed at obtaining information about their eating behaviour. These 20 questions were taken from the three-factor eating questionnaire developed by Tholin et al. (2005) and adapted to Turkish by Karakuş et al. (2016). Participants were requested to answer these 20 questions by taking into account the situation before COVID-19 and during COVID-19. The second section of the questionnaire included four questions regarding the demographic characteristics of the participants. The questionnaires were filled in online on May 18-31, 2020.

A total of 397 people completed the questionnaire in the context of the study, and the questionnaires were transferred to the computer environment, and then analyses were performed on this data. Cronbach Alpha test was used to check the reliability of the questionnaire (Ural and Kilıç, 2005). Confirmatory Factor Analysis (CFA) was performed for the construct validity of the questionnaire (Çokluk et al. 2010). In addition, frequency and percentage analyses were used to determine the demographic characteristics of the participants and the change in their eating behaviour. Finally, independent samples t test and one-way analysis of variance (ANOVA) were performed to determine whether the change in the eating behaviour of the participants differed according to their demographic characteristics (Büyüköztürk, 2010).

\section{Analysis and Findings}


A total of 397 questionnaires filled out by the participants for the study were transferred to the computer environment and the analyses were performed on this data. Frequency analysis was carried out to find out the demographic distribution of the participants. Information obtained regarding the analysis for the demographic distribution of the participants is presented in Table 1 below.

Table 1: The frequency distributions for the demographic characteristics of the participants

\begin{tabular}{|c|c|c|c|c|}
\hline \multicolumn{2}{|c|}{ Demographic Characteristics } & \multirow{2}{*}{$\begin{array}{c}\text { Distribution } \\
\\
24 \\
\end{array}$} & \multirow{2}{*}{$\begin{array}{l}\begin{array}{l}\text { Percentage } \\
(\%)\end{array} \\
\quad 6,0 \\
\end{array}$} & \multirow{2}{*}{$\begin{array}{c}\text { Total } \\
\begin{array}{c}\text { Percentage } \\
(\%)\end{array} \\
\\
\\
6,0 \\
\end{array}$} \\
\hline \multirow{5}{*}{ Age } & $\begin{array}{l}18-20 \\
\text { years }\end{array}$ & & & \\
\hline & $\begin{array}{l}\text { 21-35 } \\
\text { years }\end{array}$ & 152 & 38,3 & 44,3 \\
\hline & $\begin{array}{l}\text { 36-50 } \\
\text { years }\end{array}$ & 160 & 40,3 & 84,6 \\
\hline & $\begin{array}{l}51 \text { years } \\
\text { and above }\end{array}$ & 61 & 15,4 & 100,0 \\
\hline & Total & 397 & 100,0 & \\
\hline \multirow{3}{*}{ Gender } & Female & 158 & 39,8 & 39,8 \\
\hline & Male & 239 & 60,2 & 100,0 \\
\hline & Total & 397 & 100,0 & \\
\hline \multirow{4}{*}{$\begin{array}{l}\text { Educational } \\
\text { Background }\end{array}$} & $\begin{array}{l}\text { Secondary } \\
\text { School }\end{array}$ & 22 & 5,5 & 5,5 \\
\hline & $\begin{array}{c}\text { High } \\
\text { School }\end{array}$ & 90 & 22,7 & 28,2 \\
\hline & University & 285 & 71,8 & 100,0 \\
\hline & Total & 397 & 100,0 & \\
\hline \multirow{4}{*}{ Income } & $\begin{array}{l}\text { Below } \\
3000 \text { TL } \\
\end{array}$ & 135 & 34,0 & 34,0 \\
\hline & $\begin{array}{l}3001- \\
5000 \mathrm{TL} \\
\end{array}$ & 123 & 31,0 & 65,0 \\
\hline & $\begin{array}{l}5001 \mathrm{TL} \\
\text { and above }\end{array}$ & 139 & 35,0 & 100,0 \\
\hline & Total & 397 & 100,0 & \\
\hline
\end{tabular}

Table 1 indicates that the majority of the participants (78.6\%) were $21-50$ years old, university graduates $(71.8 \%)$ and male $(60.2 \%)$. Considering the income levels of the participants, it is observed that there is a balanced distribution.

After examining the frequency distributions, Cronbach's Alpha test was conducted to test the reliability of the questionnaire. Although there are different types of analysis to measure reliability, the most commonly used one is the Cronbach's Alpha coefficient (Özdamar, 2004). According to the results of the reliability analysis in the present study, the Cronbach's Alpha coefficient of the three-factor eating questionnaire was found to be ,845. This coefficient shows that the questionnaire is highly reliable (Kalayc1, 2010). 
Confirmatory Factor Analysis (CFA) was conducted to test the construct validity of the questionnaire. This is because CFA can be used to test whether a previously defined and restricted construct is verified as a model (Çokluk et al. 2014).

As a result of the CFA analysis, the values for the fit indices were determined as: $\chi 2=454,88, \quad \mathrm{sd}=167, \mathrm{p}<0.000), \quad \mathrm{RMSEA}=0,066, \quad \mathrm{RMR}=0,063, \mathrm{GFI}=0,90, \quad \mathrm{AGFI}=0,87$, $\mathrm{NFI}=0,96, \mathrm{NNFI}=0,97$. According to these results, it can be stated that the model had an acceptable fit. The path diagram for the CFA analysis including the standardized solutions is shown in Figure 1 below.

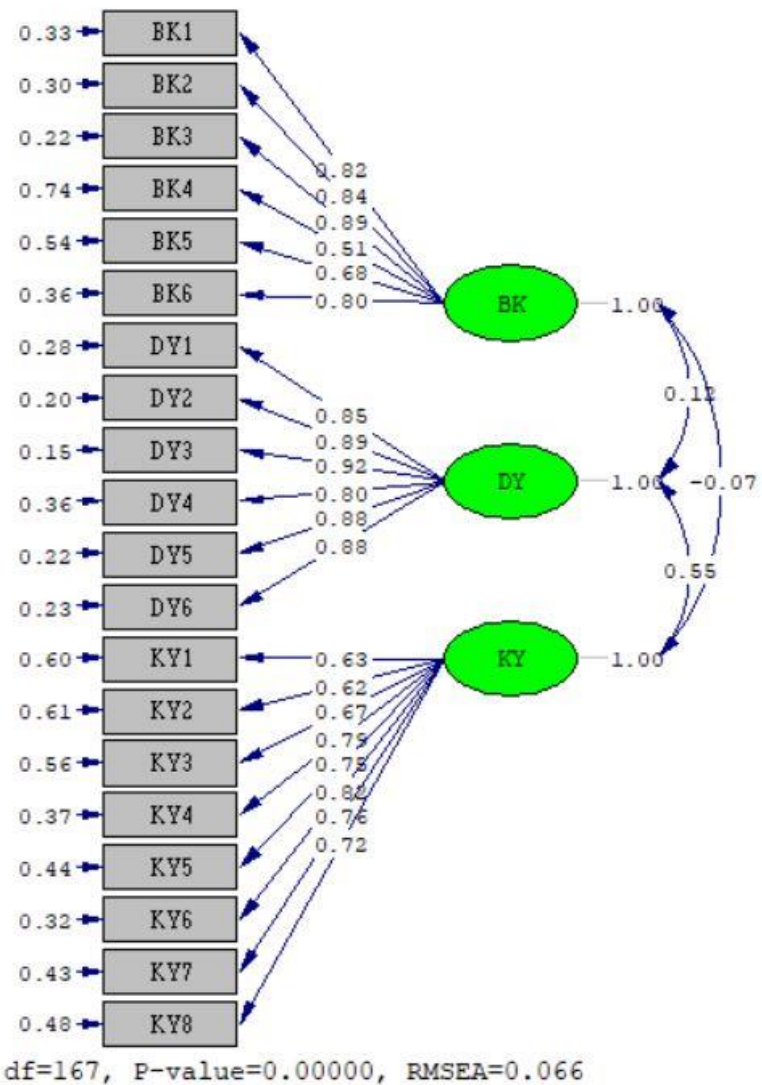

Figure 1: Path diagram for CFA analysis

The latent variables given in Figure 1 are defined as BK $=$ Cognitive Restraint, DY = Emotional Eating and $\mathrm{KY}=$ Uncontrolled Eating. As can be seen in the figure, the observed variables for the latent variables are 6 (BK1 ....BK6) for Cognitive Restraint, 6 (DY1 ....DY6) for Emotional Eating and 8 (KY1 ...KY8) for uncontrolled eating, which make up 20 variables in total. As revealed in the figure, the $\mathrm{t}$ values of the items were significant at the 0.05 level.

Table 2: $T$ test table showing the difference in eating behaviour before COVID-19 and during COVID-19 


\begin{tabular}{|c|c|c|c|c|c|c|c|}
\hline $\begin{array}{c}\text { Eating } \\
\text { Behaviour }\end{array}$ & od Peri & $\mathbf{N}$ & $\ddot{\mathbf{X}}$ & Sd. & $\mathbf{t}$ & & \\
\hline \multirow{2}{*}{$\begin{array}{l}\text { Cognitive } \\
\text { Restraint }\end{array}$} & $\begin{array}{l}\text { Befo } \\
\text { re COVID- } \\
19\end{array}$ & $97^{3}$ & $41^{2,93}$ & $1^{, 8995}$ & \multirow{2}{*}{$4^{7,6}$} & \multirow[b]{2}{*}{96} & \multirow[b]{2}{*}{01} \\
\hline & $\begin{array}{c}\text { Duri } \\
\text { ng COVID- } \\
19\end{array}$ & $97^{3}$ & $11^{2,59}$ & $1^{, 8083}$ & & & \\
\hline \multirow{2}{*}{$\begin{array}{l}\text { Emotiona } \\
\text { 1 Eating }\end{array}$} & $\begin{array}{l}\text { Befo } \\
\text { re COVID- } \\
19\end{array}$ & $97^{3}$ & $95^{2,37}$ & $24^{1,071}$ & \multirow[b]{2}{*}{11,707} & \multirow[b]{2}{*}{96} & \multirow[b]{2}{*}{01} \\
\hline & $\begin{array}{c}\text { Duri } \\
\text { ng COVID- } \\
19\end{array}$ & $97^{3}$ & $99^{3,31}$ & $56^{1,130}$ & & & \\
\hline \multirow{2}{*}{$\begin{array}{l}\text { Uncontrol } \\
\text { led Eating }\end{array}$} & $\begin{array}{c}\text { Befo } \\
\text { re COVID- } \\
19 \\
\end{array}$ & $97^{3}$ & $90^{2,48}$ & $1^{, 7990}$ & \multirow{2}{*}{$11,541^{-}$} & \multirow{2}{*}{$96^{3}$} & \multirow[b]{2}{*}{01} \\
\hline & $\begin{array}{c}\text { Duri } \\
\text { ng COVID- } \\
19\end{array}$ & $97^{3}$ & $98^{3,17}$ & $8^{, 8992}$ & & & \\
\hline
\end{tabular}

Table 2 illustrates the results of the $\mathrm{T}$ test revealing the difference in eating behaviour of the participants before COVID-19 and during COVID-19. As can be seen from the table, there is a significant difference in the eating behaviour of the participants between the period before COVID-19 and during the COVID-19 period. As can be seen from the mean values presented in the table, there was a decrease in the Cognitive Restraint behaviour of the participants and an increase in the Emotional Eating behaviour and Uncontrolled Eating behaviour during COVID-19 compared to the situation before COVID-19. These results provide an answer to the first and second research questions (RQ1 and RQ2) of the study.

Table 3: Anova test table showing the difference in eating behaviour during COVID-19 based on age 


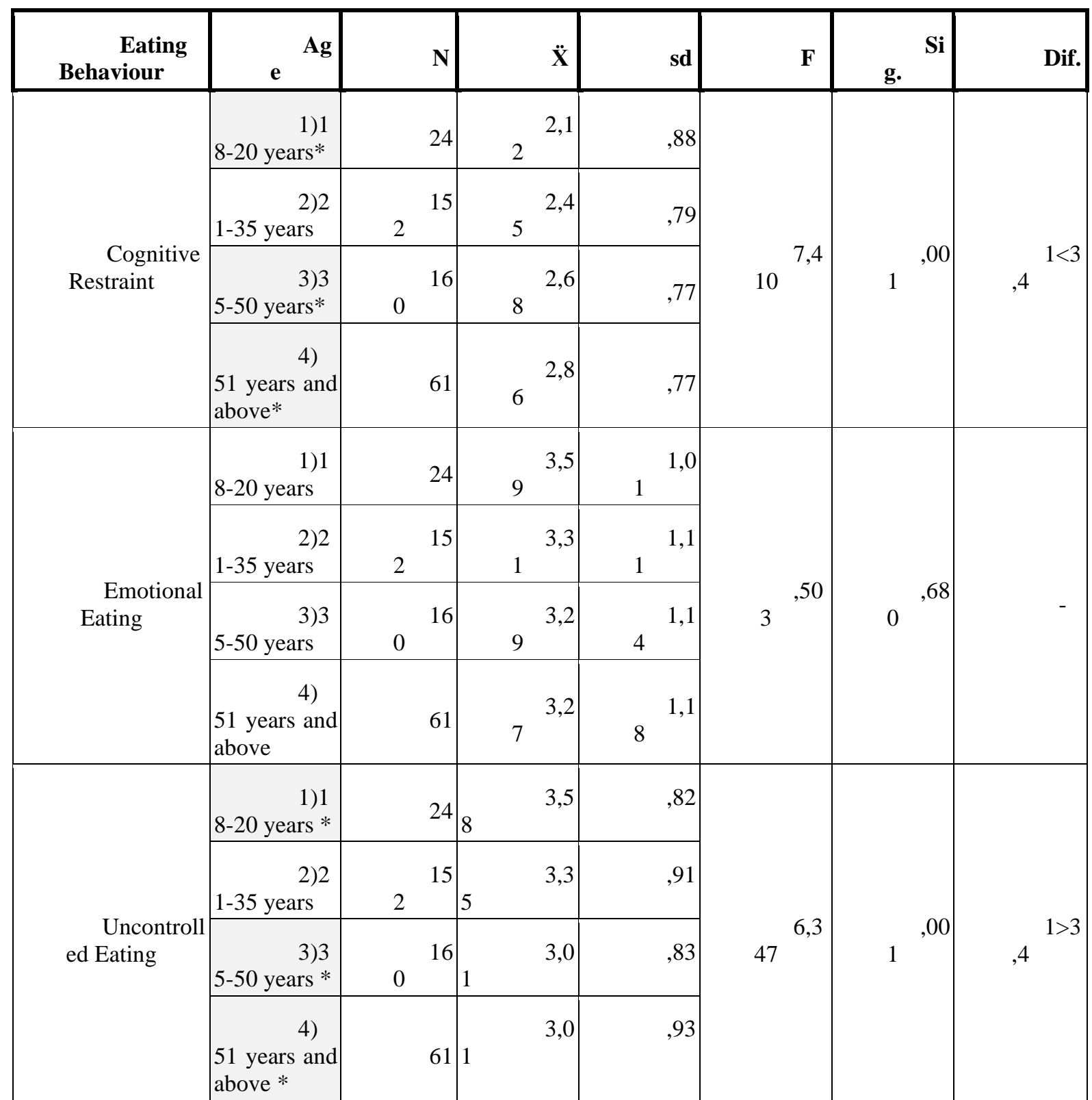

Table 3 indicates whether the participants' eating behaviour during COVID-19 differed by age. It can be understood that there was a difference in the participants' Cognitive Restraint and Uncontrolled Eating behaviour based on age, but that no difference was observed in their Emotional Eating behaviour. In the Cognitive Restraint behaviour, the mean of those aged 1820 was lower than those aged 35 and above, while the mean of those aged 18-20 years was found to be higher compared to the same age range in Uncontrolled Eating behaviour.

Table 4: Anova test table showing the difference in eating behaviour during COVID-19 based on income level 


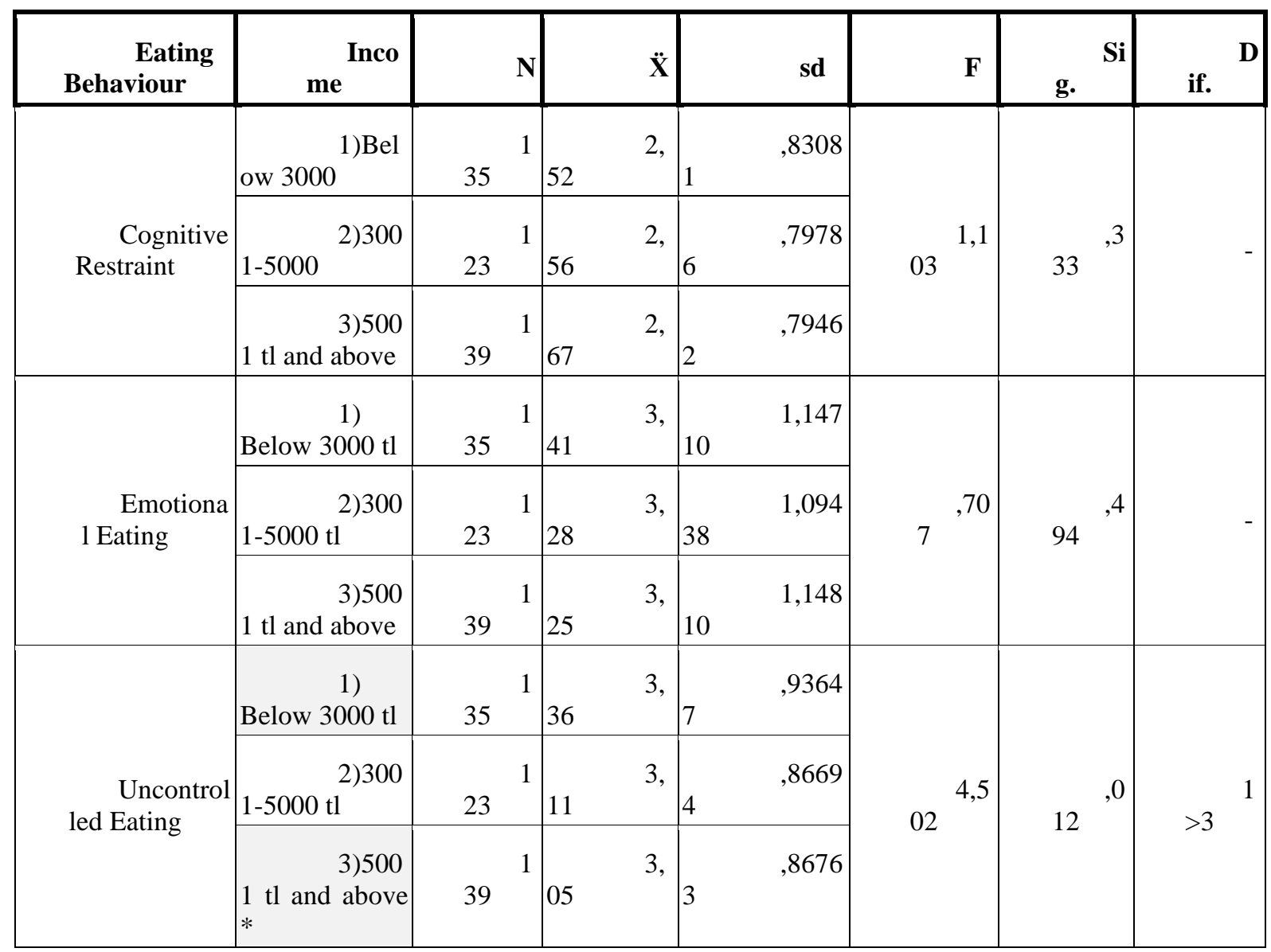

Table 4 demonstrates whether the participants' eating behaviour during COVID-19 differed by their income levels. As can be seen in the table, a difference was observed in the cognitive restraint and emotional eating behaviours of the participants according to their income levels. However, it is understood that the difference found in the Uncontrolled Eating Behaviour of the participants based on income was between those with an income below $3000 \mathrm{TL}$ and those with an income of 5001 TL or above.

The results given in Table 3 and Table 4 provide an answer to the third research question (RQ3), which is "Does the change in the eating behaviour of people differ according to their demographic characteristics during COVID-19?". T test and Anova test analyses were conducted to determine whether the eating behaviour of the participants differed according to their gender and educational background. However, since no significant difference was determined in either analysis, it was found unnecessary to present the results in a table.

\section{Conclusion and Recommendations}

In the analysis and findings section, Table 1 demonstrates that the majority of the participants are middle-aged, university graduates and males. This result may be due to the participant profile that researchers managed to reach under restricted and extraordinary conditions, as well as the sensitivity of this group of people to participate in such scientific studies. Researchers may be advised to conduct studies on the tendency and causes of participants to take part in scientific research.

As can be seen in Table 2, there is a significant difference in the participants' eating behaviour before COVID-19 and during the COVID-19. According to the table, during COVID-19, there is a decrease in the participants' Cognitive Restraint behaviour and an increase in their Emotional Eating and Uncontrolled Eating behaviour. These results are in 
parallel with the studies examined on the subject in the literature review section. In these studies, it is emphasized that negative emotional states such as depression, stress and boredom have an impact on eating habits. The extraordinary and unexpected conditions due to COVID19 are likely to trigger and/or increase stress, depression, and boredom in people. Researchers are advised to contribute to the generalizability of the results by carrying out studies on this issue. Furthermore, it is recommended that researchers conduct research on eating behaviour after COVID-19 and find out whether the situation that emerged during COVID-19 still continues or not, and if not, they are advised to carry out studies on the direction of the change. In addition, food and beverage businesses may be recommended to do planning for the new eating behaviour that occurs in consumers in order to meet their consumers' expectations in the best way.

Table 3 given in the Analysis and Findings section indicates whether the eating behaviour of the participants during COVID-19 differs according to age. It can be seen that there is no difference in Emotional Eating behaviour, while a difference is observed in Cognitive Restraint and Uncontrolled Eating behaviour. The difference seems to be between the participants aged 18-20 and those aged 35 and above; and while the mean of those in the 18-20 age group is lower in Cognitive Restraint behaviour, their mean in Uncontrolled Eating behaviour is determined to be higher. This may have resulted from young people's need to consume more food, or it could be because they are more sensitive about controlling their stress, boredom and depression than those aged 35 and above. Researchers may be advised to conduct research on the emotional states of people in this age range during COVID-19. What is more, the relevant ministries (Ministry of Health, Ministry of National Education, etc.) may be recommended to develop programs that can regulate the emotional state, psychology and eating behaviour of young people. In addition, it is recommended that food and beverage businesses, whose customer profile is composed of young people, should make plans that will help their customers have a healthy and balanced diet considering this situation. The last Table (Table 4) included in the study reveals whether the participants' eating behaviour differs during COVID-19 based on their income levels. It is understood from the table that there is a difference in the Uncontrolled Eating behaviour between the participants with an income of $3000 \mathrm{TL}$ and below and those who had an income of $5001 \mathrm{TL}$ and above. The mean of the participants who had an income of $3000 \mathrm{TL}$ and below is found to be higher than the mean of those with an income of $5001 \mathrm{TL}$ and above in the Uncontrolled Eating behaviour. Researchers are advised to conduct studies on the causes of the change in Uncontrolled Eating behaviour of the people in this group and develop suggestions in line with the scientific results revealed.

\section{References}

Altun, M. \& Kutlu, Y. (2015). Ergenlerin yeme davranışları ile ilgili görüşleri: niteliksel çalışma. Florence Nightingale Hemşirelik Dergisi. 23(3), 174-184.

Altunışık, R., Çoşkun, R., Bayraktaroğlu, S. \& Yıldırım, E. (2007). Sosyal bilimlerde araştırma yöntemleri: spss uygulamall. (5th edition enhanced). Adapazarı: Sakarya Yayınc1lık.

Büyüköztürk, Ş. (2010). Sosyal bilimler için veri analizi el kitabı. (12th edition). Ankara Pegem Yayınları.

Çokluk, Ö., Şekercioğlu, G. \& Büyüköztürk, Ş. (2014). Sosyal bilimler için çok değişkenli istatistik. (3th edition) Ankara: Pegem Yayınları.

Çokluk, Ö., Şekercioğlu, G. \& Büyüköztürk, Ş. (2010). Sosyal bilimler için çok değişkenli istatistik. spss ve lisrel uygulamalart. Ankara: Pegem Yayınları. 
Demir, M., Günaydın, Y. \& Demir, Ș.Ş. (2020). Coronavirüs (covid-19)'ün türkiye'de turizm üzerindeki öncüllerinin, etkilerinin ve sonuçlarının değerlendirilmesi. International Journal of Social Sciences and Education Research, 6(1), 80-107.

Dovey T. M. (2010). Eating behaviour. London: Mc Graw-Hill Education.

Gibson E.L. (2012) The psychobiology of comfort eating: implications for neuropharmacological interventions, Behavioural Pharmacology. 23, 442-460.

Groesz, L. M., McCoy, S., Carl, J., Saslow, L., Stewart, J., Adler, N., Laraia, B., \& Epel, E. (2012). What is eating you? Stress and the drive to eat. Appetite, 58(2), 717-721.

Higgs, S. (2015). Social norms and their influence on eating behaviours. Appetite. 86, 38-44.

Nalçacı İkiz, A. (2019). TFEQ-R21 ile üniversite öğrencilerinin yeme davranışlarının incelenmesi. Journal of Tourism and Gastronomy Studies, 7(2), 968-979.

Karakuş, S.Ş., Yıldırım, H. \& Büyüköztürk, Ş. (2016). Üç faktörlü yeme ölçeğinin türk kültürüne uyarlanması: geçerlik ve güvenirlik çalışması. TAF Prev Med Bull. 15(3), 229-237.

Karaoğlu, M. \& Erzi, S. (2019). Yeme tutumları ve travmatik yaşantılar: Öz şefkat ve duygu düzenlemenin aracı rolü. Kıbrıs Türk Psikiyatri ve Psikoloji Dergisi, 1(3), 145-151.

Koball, A., Meers, M.R., Storfer-Isser, A., Domoff, S.E. \& Musher-Eizenman, D.R. (2012). Eating when bored: Revision of the emotional eating scale with a focus on boredom. Health Psychol. 31, 521-524.

Konttinen, H., Mannisto, S., Sarlio-Lahteenlorva, S,. Silventoinen, K. \& Haukkala, A. (2010). Emotional eating and physical activity self-efficacy as pathways in the association between depressive symptoms and adiposity indicators. Am J Clin Nutr. 92(5), 10311039.

Orbatu, D.S. (2020). İzmir ili lise çağı çocuklarında yeme farkındalığının değerlendirilmesi. Tepecik Eğit. ve Araşt. Hast. Dergisi. 30(1), 19-27.

O'Reilly, G.A., Look, L. \& Spruijt-Metz, D. (2014). Mindfulness-based interventions for obesity-related eating behaviours: a literature review. Obesity Reviews, 15, 453-461.

Özdamar, K. (2004). Paket programlar ile istatistiksel veri analizi 2. (5th Edition), Eskişehir:Kaan Kitapevi.

Tanrıverdi, Z. (2020). Üniversite öğrencilerinin duygusal yeme davranışlarının ve duygusal iştahlarının incelenmesi. Yayımlanmamış Yüksek Lisans Tezi. Çağ Üniversitesi Sosyal Bilimler Enstitüsü, Adana.

Tholin, S., Rasmussen, F., Tynelius, P. \& Karlsson J. (2005). Genetic and environmental influences on eating behaviour: the swedish young male twins study. The American Journal of Clinical Nutrition. 81(3), 564-569.

Ural, A. \& Kılıç, İ. (2005). Bilimsel araştırma süreci ve spss ile veri analizi. Ankara, Detay Yayıncilik.

Zellner, D. A., Loaiza, S., Gonzalez, Z., Pita, J., Morales, J., Pecora, D., \& Wolf, A. (2006). Food selection changes under stress. Physiology and Behavior, 87(4), 789-793. 